\title{
KINERJA BENTUK BANGUNAN PERKANTORAN BERTINGKAT MENENGAH DI SURABAYA TERHADAP EFISIENSI ENERGI PENDINGINAN
}

\author{
Dian Pramita Eka Laksmiyanti \\ Institut Teknologi Adhi Tama Surabaya \\ Email: dianpramita@itats.ac.id
}

\begin{abstract}
ABSTRCT
Climate element can be both, advantage and threat for architect in tropical region. High sun shine duration all year encourage us to use daylight as much as we need, which is means user can use less operational energy for lighting. Unfortunately, instead of save the energy, too much opening in a building brings high solar irradiance to the building and rise up the indoor temperature. Multi-storey buildings are especially vurnarable as far as heat is concerned. Greater area of the facade is exposed and will be the main source of heat input, which in turns will have an impact on energy use and comfort. Carefull considerations on the design of form and envelope are prooved to be of advantage in terms of energy performance. This research aims to analyse energy performance of middle-rise buildings, especially in relation to cooling, and its relation the form and facade of the buildings. Some sample of middle-rise office buildings in Surabaya were taken, representing the exististing types. Simulation was conducted to predict energy performance for cooling at two critical months of the year. Energy performance of the buildings were found to bear some relations to form and envelope
\end{abstract}

Keywords: Energy for cooling, middle-rise building, office, tropics

\begin{abstract}
ABSTRAK
Iklim tropis dapat menjadi keuntungan sekaligus tantangan bagi seorang arsitek. Daerah tropis mendapat cahaya matahari sepanjang tahun, itu artinya dapat menghemat energi pencahayaan sekaligus banyak panas yang masuk ke dalam bangunan. Seorang arsitek harus mampu mengoptimalkan iklim agar bangunan yang dibuat lebih efisien terhadap penggunaan energi. Pada daerah tropis, temperatur udara dan radiasi matahari yang tinggi menjadi tantangan utama seorang arsitek terutama pada bangunan bertingkat. Bangunan bertingkat menengah memiliki luas permukaan selubung yang lebih besar disbanding bangunan bertingkat rendah, itu artinya makin banyak bidang penerima panas pada bangunan sehingga beban pendinginan akan meningkat. Banyak strategi yang dapat diambil oleh arsitek untuk mengurangi beban pendinginan, antara lain dengan memodifikasi bentuk dan material selubung bangunan. Penelitian ini bertujuan untuk menganalisa kinerja energi pendinginan pada bangunan bertingkat menengah di Surabaya, serta pengaruh bentuk bangunan terhadap efisiensi energi pendinginan. Metode yang digunakan dalam penelitian ini adalah metode eksperimen dengan taktik simulasi. Bentuk bangunan yang ada di lapangan digenerlisir dan digunakan sebagai sample yang mewakili satu tipe bentuk. Simulasi dilakukan untuk menghitung beban pendinginan pada masing-masing sample, kemudian menganalisa hubungan bentuk bangunan dengan kinerja energi pendinginan. Secara umum $s / v$ ratio berbanding lurus dengan beban pendinginan, namun dalam penelitian ini terdapat beberapa kasus yang berbeda. Dari penelitian ini didapat bahwa bangunan dengan bentuk octagon memiliki kinerja paling baik.
\end{abstract}

Keywords: Bangunan Bertingkat, Bentuk, Energi Pendinginan, Perkantoran, Tropis

\section{PENDAHULUAN}

Peningkatan energi pada bangunan terutama sektor komersial telah melonjak pada akhir dekade ini [1]. Untuk melakukan penghematan, Green Building Council Indonesia memiliki satu standard labelling untuk bangunan baru maupun yang sudah ada. Bangunan akan dikatakan efisien terhadap penggunaan energy jika penggunaan daya listriknya tidak lebih dari $200 \mathrm{kWh} / \mathrm{m} 2 /$ tahun untuk semua elemen. BPPT menetapkan besarnya energi listrik untuk pengkondisian udara sebesar 47\% dari angka Energi Efisien Index atau sekitar [2]. 
Bangunan di daerah tropis dibangun dengan facade yang hampir sama, berbentuk box dengan facade kaca, padahal iklim di masing masing daerah berbeda, itu berarti performance bangunan terhadap iklim tidak optimal, padahal efisiensi energy dapat dicapai dengan memperhatikan kaitan desain bangunan dengan iklim setempat [3,4]. Bangunan hemat energi dipengaruhi oleh denah, bentuk, konfigurasi massa dan potongan bangunan. Dengan volume yang sama dan luas selubung yang berbeda, beban pendinginan pada bangunan akan berbeda, ini berkaitan dengan permukaan yang menutup bangunan atau s/v ratio [5]. Semakin besar permukaan semakin besar pula panas yang diterima [6]. Selain dipengaruhi oleh luas selubung bangunan, heat flow pada bangunan juga dipengaruhi oleh material selubungnya [7-10].

Surabaya, salah satu kota di negara tropis lembab, pada tiga tahun belakangan ini hingga tiga tahun kedepan akan mengalami pertumbuhan pembangunan gedung perkantoran yang cukup signifikan. Hal ini disebabkan oleh lonjakan harga tanah yang cukup tinggi di Surabaya. Colliers International Indonesia mencatat setidaknya terdapat 26 proyek pembangunan gedung perkantoran yang dikembangkan pada tahun 2012 di Surabaya [7]. Pada agenda 21 telah disusun konsep dan aturan umum untuk pembangunan berwawasan lingkungan. Salah satu strategi dari pembangunan berwawasan lingkungan adalah penghematan energi pada sektor bangunan. Penelitian ini bertujuan unntuk menganalisa kinerja energi pendinginan pada bangunan perkantoran bertingkat menengah di Surabaya. Studi yang sebelumnya banyak dilakukan pada bangunan prismatik persegi maupun persegi panjang. Kali ini akan dikaji pengaruh bentuk yang lain terhadap energi pendinginan serta kinerja material pada bangunan tersebut.

\section{TINJAUAN PUSTAKA}

\section{Bangunan Hemat Energi}

Persyaratan mendasar sebuah bangunan ada lima, yang pertama, bangunan harus dibuat berdasarkan pada budaya pembangunan setempat, kedua, bangunan harus dapat mengontrol lingkungan internal untuk kenyamanan pengguna bangunan. ketiga, bangunan harus medukung aktifitas sosial pengguna, keempat, harus mampu memberikan reaksi terhadap gaya dari luar, misalnya struktur bangunan tradisional yang mampu bertahan dari gempa atau pergeseran tanah atau Desainnya yang mampu menjawab permasalahan iklim. Kelima, bangunan memenuhi persyaratan pertama hingga keempat dengan biaya yang masuk akal dan hemat dalam penggunaan energi, baik embodied energy maupun energi operasional [11]. Bangunan hemat energi adalah bangunan yang memiliki keseimbagan energi [12]. Faktor-faktornya antara lain:

- Pengoptimalan penggunaan internal heating load yang tinggi

- Menghindari overheating

- Perlindungan dari panas matahari dan silau

- Pengoptimalan pencahayaan alami

- Fleksibilitas dalam penggantian dan perawatan alat di bangunan tanpa konsumsi energi yang berlebihan

Keseimbangan energi adalah keseimbangan antara energi yang dikeluarkan dan energi yang masuk ke dalam bangunan. Misalnya kehilangan thermal comfort dalam banunan harus diimbangi dengan adanya sun protection atau insulasi yang baik pada selubung sehingga tidak ada tambahan energi dari luar (untuk Air Conditioner). Energy balance bisa dipengaruhi oleh planning, teknologi dan konstruksi bangunan. Bangunan komersial memiliki internal load yang tinggi, maka desain yang dianjurkan adalah desain dengan banyak jendela sehingga memungkinkan untuk pencahayaan alami [12]. Dampak negatifnya adalah di iklim tropis radiasi matahari bisa ikut masuk dan menyebabkan temperatur ruang dalam naik sehingga perlu ada sistem tata udara yang efisien.

Studi sebelumnya yang menggunakan LT Method, Desain parameter seperti building plan, orientasi dan desain fasade mempengaruhi pengunaan energi 2.5 kali. Artinya, jika dibandingkan, desain yang buruk akan mengkonsumsi energi 2.5 kali lebih besar dari bangunan degan desain yang baik. Bangunan dengan desain buruk dan sistem buruk, konsumsi energinya lima kali desain yang baik dengan sistem yang baik. Kebiasaan penghuni juga mempengaruhi jumlah konsumsi 
energi. Kebiasaan penguhuni yang buruk dapat menaikkan konsumsi energi hingga dua kali lipat [5].

Indonesia telah memiliki standard untuk suatu bangunan yang dapat dikatakan efisien terhadap penggunaan energi. Standart tersebut dirangkum dalam beberapa aturan SNI. Terdapat dua tipe building codes, yang pertama, kinerja bangunan dilihat perbagian, terutama dari kinerja selubung bangunan dan peralatan yang digunakan di bangunan tersebut. Yang kedua dengan melihat semua kinerja elemen bangunan dengan melihat level konsumsi energi, energy cost budget. Tolok ukur yang digunakan untuk evaluasi efisiensi energi pada suatu bangunan adalah EEI (energy efficient index). Negara di Asia Tenggara memiliki EEI antara 150-200 $\mathrm{kWh} / \mathrm{m} 2 /$ tahun merupakan bangunan yang efisien dalam penggunaan energi. India menetapkan EEI antara $100-150 \mathrm{kWh} / \mathrm{m} 2 /$ tahun untuk bangunan yang dinilai efisien .

SNI 03-6389-2000 menjelaskan mengenai konservasi energi melalui selubung bangunan dengan menghitung OTTV dan RTTV bangunan. untuk Indonesia OTTV maksimal untuk tower adalah $35 \mathrm{~W} / \mathrm{m} 2$. OTTV merupakan salah satu variabel penghematan energi pendinginan, namun tidak dapat langsung dijadikan parameter tunggal [13].

\section{Elemen Bentuk}

Bentuk geometri digambarkan secara lengkap dalam sebuah bidang pada selembar kertas. Untuk lebih jelasnya seperti yang ada di gambar di bawah ini. Gambar tersebut adalah gambar kubus, permukaan sebuah kubus adalah bujur sangkar. Sisi-sisinya bertemu pada rusuk. Ujung kubus disebut "vertices". Komponen ini akan memberi karakter pada bentuk bangunan [9]. Istilah yang sering digunakan dalam komponen geometri:

- Luas atau Area: ukuran permukaan yang tertutup oleh bidang terbangun

- Luas permukaan: jumlah area yang akan tertutup jika bangunan tersebut dikuliti

- Volume: kapasitas isi suatu ruang

\section{a. Perbandingan panjang terhadap lebar bangunan}

Perbandingan panjang terhadap lebar bangunan atau w/l ratio biasa digunakan dan lebih mudah dipahami dalam semua tipe bangunan. Rasio ini mempengaruhi tingkat insolation yang diterima permukaan bangunan. Rasio ini juga berpengaruh pada aliran angindi sekitar yang akan mempengaruhi ventilasi bangunan. Pengaruh iklim pada bentuk bangunan bertingkat. Bentuk bangunan yang beragam memiliki sudut jatuh matahari yang beragam pula untuk masing-masing iklim. Untuk daerah iklim dingin, disarankan menggunakan bentuk silinder dengan W/L ratio 1:1. Untuk daerah iklim sedang, tropis kering dan tropis lembab, rasio yang digunakan berturut-turut 1:1.6, 1:2 dan 1:3. rasio ini menunjukkan bahwa meminimalkan panjang sisi dengan orientasi barat dan timur sangat penting terutama untuk daerah dengan garis lintang rendah $[4,10]$.

\section{b. Perbandingan luas permukaan selubung terhadap volume bangunan}

Perbandingan luas permukaan yang digunakan untuk menutup sebuah volume bangunan atau s/v ratio merupakan salah satu parameter desain yang mempengaruhi heat gain pada bangunan (markus, 1980). Rasio ini sedikit berbeda dengan exposed area to volume ratio. Permukaan yang ter-expose berarti permukaan bangunan yang secara langsung terkena lingkungan luar. Bidang yang berada di atas tanah bukanlah termasuk exposed surface dan terhitung dalam s/v ratio. Bentuk yang terbaik di daerah iklim temperate adalah bangunan dengan heat loss terkecil sedangkan untuk area tropis bentuk bangunan terbaik adalah bangunan dengan heat gain terendah, sehingga berbicara mengenai s/v ratio pada bangunan tropis lebih mengarah pada exposed area to volume ratio [6].

Konfigurasi bangunan yang ideal menggunakan $\mathrm{s} / \mathrm{v}$ ratio berdasarkan pada rata-rata heat gain. Bangunan dapat diasumsikan memiliki tiga komponen yang dapat mentransmisikan radiasi. Tiga komponen itu adalah dinding yang bersifat opaque, jendela, dan atap. Pada masing-masing komponen itu, perolehan radiasi matahari rata-rata dipengaruhi oleh besar luas bidang terima dan nilai radiasi matahari. Matus (1988) menjelaskan semakin sedikit permukaan yang digunakan untuk 
menutup sebuah volume, makin kecil sistem yang dipengaruhi oleh variasi pada tekanan eksternal [6].

\section{Selubung Bangunan dan Energi Pendinginan}

Material yang digunakan suatu bangunan berhubungan langsung dengan ruang luar dan radiasi matahari yang menerpa permukaan. Temperatur luar sepenuhnya bergantung pada kondisi klimatologi, sedangkan untuk temperatur ruang dalam bergantung pada sistem penghawaan dalam bangunan. Besarnya energi yang digunakan untuk pendinginan bergantung solar control bangunan tersebut. Thermal properties yang paling berpengaruh pada kondisi panas adalah: decrement factor dan admittance dimana keduanya juga ditentukan oleh thermal properties lainnya, yakni: conductivity, specific heat dan kepadatan material [10].

\section{METODE}

Penelitian ini bertujuan untuk menganalisa kinerja bentuk bangunan perkantoran bertigkat menengah di surabaya serta pengaruh bentuk terhadap efisiensi penggunaan energi pendinginan. Secara umum penelitian ini menggunakan metode eksperimen dengan taktik simulasi. Penelitian sejenis yang juga menggunakan metode eksperimen, dengan membandingkan beban pendinginan pada beberapa bangunan bertingkat dengan geometri denah dan s/v ratio yang berbeda[8], ada juga yang membandingkan beberapa bangunan dengan bentuk dasar yang berbeda untuk mengetahui pengaruh geometri dasar denah terhadap insolation dan energi pendinginan [9]. Penelitian lainnya membandingkan satu model dasar bangunan dengan bahan dinding tanpa insulasi dan kaca bening tanpa treatment, tanpa shading kemudian dibandingkan dengan bangunan menggunakan insulasi dan mengganti dengan beberapa jenis kaca yang berbeda serta membandingkan kinerja bangunan dengan WWR yang berbeda untuk menemukan WWR optimum untuk daerah tropis dan solusi material fasade untuk beberapa bangunan bertingkat tinggi di surabaya [7]. Berdasarkan penelitian tersebut, metode yang dilakukan dalam penelitian ini menggunakan pendekatan pada metode penelitian yang dirujuk tersebut.

Variabel terikat pada penelitian ini adalah energy pendinginan dan bentuk bangunan dalam hal ini s/v ratio menjadi variable bebas. Untuk menguji kineja bentuk terhadap energi pendinginan, beberapa variabel lain disyaratkan memiliki nilai yang sama antara lain: volume, orientasi bangunan, dan material bangunan.

Teknik sampling yang digunakan adalah simple stratified random sampling, dimana populasi heterogen tetapi mempunyai strata atau lapisan yang homogeny. Survey lapangan dilakukan untuk mendapatkan populasi bangunan perkantoran bertingkat menengah di Surabaya. Dari populasi tersebut bangunan dikelompokkan berdasarkan geometri denah yang telah disederhanakan. Penyederhanaan bentuk berdasarkan bentuk yang dominan pada bangunan tersebut, kemudian masing masing bentuk dijadikan dasar untuk menguji kinerja bangunan (tabel 1). Dari bentuk yang telah disederhanakan masing masing kelompok diambil satu objek secara acak, diundi dari masing-masing kelompok tipe bentuk bangunan, sehingga ditemukan tujuh bentuk dasar bangunan yang dapat dijadikan sample (tabel 1).

Tabel.1 Kategori bentuk bangunan di lapangan

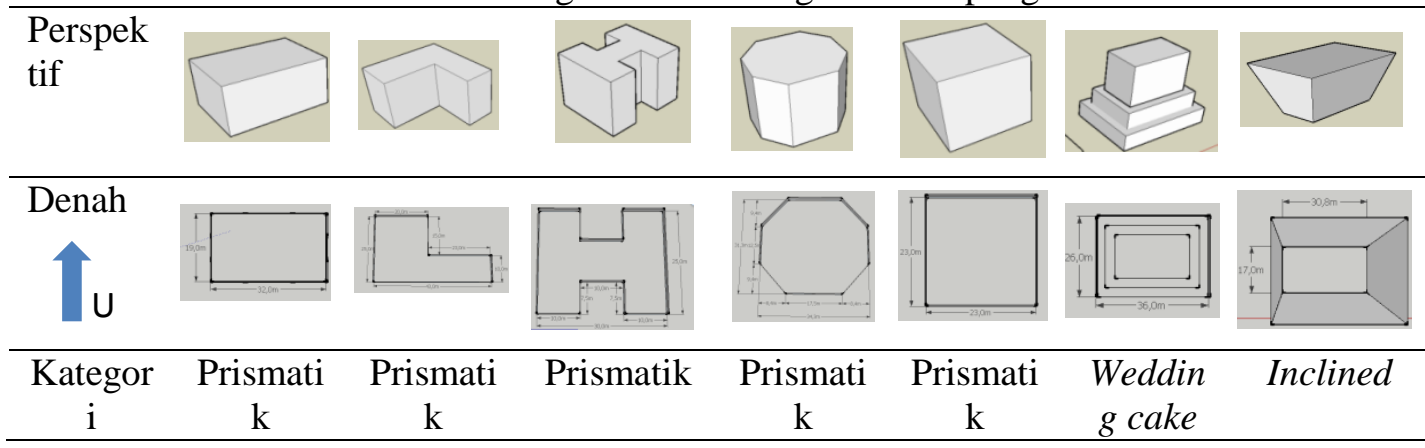


Setting eksperimen dilakukan di laboratorium dengan taktik simulasi. Simulasi komputer digunakan untuk mengontrol pengujian dengan membatasi beberapa variabel pengganggu yang cukup berpengaruh terhadap besarnya energi pendinginan dalam bangunan. Sehingga dapat diketahui pengaruh variable bebas terhadap variabel terikat yang diukur. Variabel pengganggu tersebut antara lain WWR, orientasi bangunan, volume, dan material selubung serta atap.

Untuk dapat memperoleh hubungan antara bentuk geometrid an material bangunan terhadap efisiensi energy pendinginan, serta melihat kinerja bentuk bangunan pada perkantran bertingkat menengah di Surabaya, ada beberapa variable yang harus memiliki nilai yang sama, antara lain: material, orientasi bangunan, volume bangunan, WWR, dan material serta bentuk atap. Tabel 2 menjelaskan pemodelan dan scenario eksperimen pada penelitian ini.

Tabel. 2 Bentuk yang akan diuji

\begin{tabular}{|c|c|c|c|c|c|c|c|}
\hline Skenario & $\begin{array}{l}\text { Model } \\
\text { dasar }\end{array}$ & \multicolumn{6}{|c|}{ Treatment } \\
\hline Kode & 1 & 2 & 3 & 4 & 5 & 6 & 7 \\
\hline Gambar & & & & & & & \\
\hline Volume $\left(\mathrm{m}^{3}\right)$ & 14.756 & 14.756 & 14.756 & 14.756 & 14.756 & 14.756 & 14.756 \\
\hline $\begin{array}{l}\text { Luas Lantai } \\
\left(\mathrm{m}^{2}\right)\end{array}$ & 608 & 730 & 600 & 913,77 & 529 & 936 & 527 \\
\hline $\begin{array}{ll}\begin{array}{l}\text { Luas } \\
\left(\mathrm{m}^{2}\right)\end{array} & \text { Atap } \\
\end{array}$ & 608 & 730 & 600 & 913,77 & 529 & 936 & $1.597,5$ \\
\hline $\begin{array}{l}\text { Tinggi } \\
\text { Bangunan } \\
\text { (m) }\end{array}$ & 24,27 & 20,21 & 24,59 & 16,15 & 27,89 & 30,49 & 20,00 \\
\hline $\begin{array}{l}\text { Exposed } \\
\text { Area }\left(\mathrm{m}^{2}\right)\end{array}$ & 3083,51 & 2791,80 & 4043,07 & 2694,62 & 3095,26 & 3451,14 & 4384,62 \\
\hline s/v Ratio & 0,21 & 0,19 & 0,27 & 0,18 & 0,21 & 0,23 & 0,30 \\
\hline $\begin{array}{l}\text { Rasio } \\
\text { Dinding } \\
\text { barat } \quad \& \\
\text { timur/ } \\
\text { selubung }\end{array}$ & 0,30 & 0,29 & 0,49 & 0,15 & 0,41 & 0,30 & 0,25 \\
\hline Orientasi & $\begin{array}{c}\text { Utara- } \\
\text { Selatan }\end{array}$ & $\begin{array}{l}\text { Utara- } \\
\text { Selatan }\end{array}$ & $\begin{array}{l}\text { Utara- } \\
\text { Selatan }\end{array}$ & $\begin{array}{c}\text { Utara- } \\
\text { Selatan }\end{array}$ & $\begin{array}{l}\text { Utara- } \\
\text { Selatan } \\
\end{array}$ & $\begin{array}{l}\text { Utara- } \\
\text { Selatan }\end{array}$ & $\begin{array}{c}\text { Utara- } \\
\text { Selatan }\end{array}$ \\
\hline WWR & $20 \%$ & $20 \%$ & $20 \%$ & $20 \%$ & $20 \%$ & $20 \%$ & $20 \%$ \\
\hline
\end{tabular}

Model dasar untuk penelitian ini berupa bentuk bangunan yang paling banyak digunakan di Surabaya, yaitu persegi panjang. Perbandingan antara panjang dan lebar pada denah sebesar 1:1,7. Hasil penelitian terdahulu menyatakan bahwa bangunan dengan perbandingan panjang dan lebar 1:1,7 merupakan bangunan yang paling efisien untuk daerah tropis lembab $[7,10]$. Volume untuk model dasar sebesar $14.756 \mathrm{~m}^{3}$ diambil dari rata-rata volume perkantoran bertingkat menengah di Surabaya. Dengan volume tersebut, makan panjang dan lebar sisi model dasar adalah $32 \mathrm{~m}$ x $19 \mathrm{~m}$. Dengan volume dan luas lantai tersebut, maka ketinggian bangunan sebesar 24,27m, atau sekitar 6 lantai, dengan asumsi ketinggian antar lantai sekitar $4 \mathrm{~m}$.

Dari data lapangan ditemukan beberapa bentuk dasar yang terdapat pada tabel 1. Untuk membandingkan kinerja selubung bangunan, maka volume yang bangunan yang dibandingkan harus sama. Hal ini sama dengan yang dilakukan pada penelitian sebelumnya [9]. Volume bangunan yang akan dibandingkan dalam penelitian ini didapat dari rata-rata volume bangunan perkantoran bertingkat menengah di Surabaya, sebesar $14.756 \mathrm{~m} 2$. Selain volume, variable lain 
yang harus memiliki kualitas dan kuantitas yang sama antara lain orientasi bangunan dan WWR sehingga kondisi model yang akan diuji terangkum dalam tabel 2.

\section{HASIL DAN PEMBAHASAN}

\section{Kondisi Iklim Surabaya}

Surabaya cenderung memiliki temperatur tinggi di sepanjang tahun. Dalam lima tahun terakhir temperatur udara rata-rata tertinggi ada pada bulan Oktober, dan temperatur rata rata terendah ada pada bulan Agustus dan Juli (Tabel 3). Besar kecilnya temperatur juga dapat dipengaruhi oleh elemen iklim lain seperti intensitas radiasi, lama penyinaran dan cloud cover. Makin besar intensitas radiasi, maka temperature juga makin tinggi. Curah hujan tinggi akan berpengaruh langsung pada kelembaban udara. Selain itu bulan dengan curah hujan tinggi akan memiliki cloud cover yang besar sehingga temperature udara di Surabaya tetap tinggi.

Tabel 3 Kondisi iklim Surabaya 2007-2011

\begin{tabular}{|c|c|c|c|c|c|c|c|c|c|}
\hline \multirow[t]{3}{*}{ Bulan } & \multicolumn{3}{|c|}{ Temperatur Udara } & $\begin{array}{c}\text { Kelemb } \\
\text { aban } \\
\text { Udara }\end{array}$ & $\begin{array}{c}\text { Kecep } \\
\text { atan } \\
\text { Angin }\end{array}$ & $\begin{array}{c}\text { Arah } \\
\text { Angin }\end{array}$ & $\begin{array}{c}\text { Lama } \\
\text { Penyinaran } \\
\text { Matahari }\end{array}$ & $\begin{array}{c}\text { Intesitas } \\
\text { Radiasi } \\
\text { Matahari }\end{array}$ & $\begin{array}{l}\text { Curah } \\
\text { Hujan }\end{array}$ \\
\hline & Maks & Min & $\begin{array}{c}\text { Rata- } \\
\text { rata }\end{array}$ & $\begin{array}{c}\text { Rata- } \\
\text { rata }\end{array}$ & $\begin{array}{c}\text { Rata- } \\
\text { rata } \\
\end{array}$ & $\begin{array}{c}\text { Frekue } \\
\mathrm{nsi}\end{array}$ & Rata-rata & Rata-rata & Jumlah \\
\hline & ${ }^{\circ} \mathrm{C}$ & ${ }^{\circ} \mathrm{C}$ & ${ }^{\circ} \mathrm{C}$ & $\%$ & $\mathrm{~m} / \mathrm{s}$ & & $\%$ & Watt/m2 & $\mathrm{mm}$ \\
\hline Jan & 33.8 & 23.2 & 27.4 & 80.5 & 4.3 & $\mathrm{~W}$ & 48.6 & 5756.0 & 323.76 \\
\hline Feb & 33.4 & 21.7 & 27.1 & 76.0 & 4.4 & $\mathrm{~W}$ & 55.3 & 6149.7 & 415.88 \\
\hline Mar & 33.3 & 23.2 & 27.5 & 82.8 & 3.7 & $\mathrm{E}$ & 58.6 & 6170.7 & 279.32 \\
\hline Apr & 32.9 & 23.6 & 27.7 & 82.6 & 3.3 & $\mathrm{E}$ & 58.2 & 5698.4 & 151.78 \\
\hline Mei & 32.7 & 22.5 & 28.0 & 79.6 & 3.7 & $\mathrm{E}$ & 68.8 & 5685.4 & 186.72 \\
\hline Juni & 32.4 & 22.2 & 27.4 & 77.3 & 3.8 & $\mathrm{E}$ & 81.2 & 5925.5 & 53.32 \\
\hline Juli & 32.3 & 21.0 & 26.9 & 75.7 & 4.0 & $\mathrm{E}$ & 90.8 & 6502.1 & 41.38 \\
\hline Aug & 32.6 & 21.2 & 26.9 & 73.1 & 4.2 & $\mathrm{E}$ & 93.9 & 7226.2 & 3.10 \\
\hline Sep & 33.8 & 22.4 & 27.5 & 70.3 & 4.2 & $\mathrm{E}$ & 89.5 & 7608.5 & 25.86 \\
\hline Okt & 34.8 & 23.3 & 28.9 & 70.4 & 4.3 & $\mathrm{E}$ & 80.4 & 7450.0 & 67.10 \\
\hline Nov & 34.4 & 23.6 & 28.4 & 75.9 & 3.7 & $\mathrm{E}$ & 62.9 & 6520.4 & 142.58 \\
\hline Des & 33.6 & 23.2 & 27.8 & 80.1 & 3.8 & W & 42.6 & 5382.4 & 365.06 \\
\hline
\end{tabular}

Keterangan :

$=$ Bulan Terdingin

Sumber: BMKG Juanda,2012

Dari psycrometric chart (gambar 1) dapat dilihat pada bulan terpanas dan terdingin Surabaya berada di luar zona nyaman. Pada Bulan terpanas temperatur tinggi dengan kelembapan yang relatif rendah, sedangkan pada bulan terdingin cenderung mempunyai temperatur rendah dengan kelembaban dan radiasi tinggi. Tingginya temperature, radiasi matahari, serta kelembaban akan mengakibatkan ketidak nyamanan termal. Hal ini memicu penggunaan AC yag berlebihan terutama pada bangunan perkantoran. 


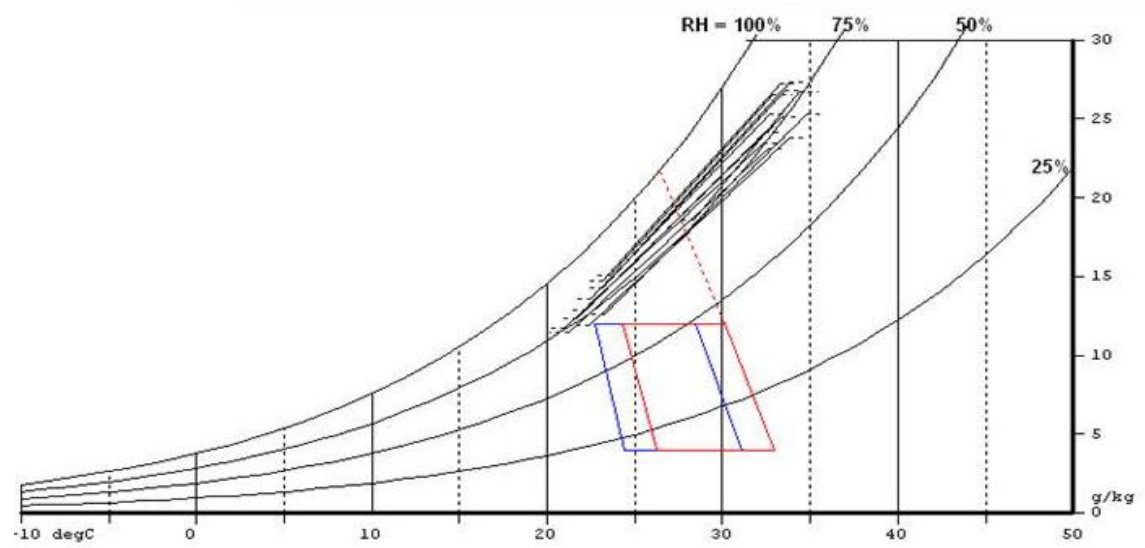

Gambar 1. Psycrhometric chart Surabaya 2007-2011 (Sumber: Archipak)

\section{Kinerja Energi pada Perkantoran Bertingkat Menengah}

Dengan menggunakan bahan bata plester untuk dinding tak tembus cahaya dan clear glass untuk dinding tembus cahaya, dari enam bangunan yang dibandingkan dengan model dasar (model 1), lima diantaranya memiliki beban pendinginan lebih besar dari model dasar. Model yang memiliki beban pendinginan lebih rendah dari model dasar hanya model 4 atau octagon (tabel 4).

Tabel 4. Beban pendinginan model 1 s.d model 7

\begin{tabular}{|c|c|c|c|c|c|c|}
\hline Model & s/v ratio & $\begin{array}{l}\text { Selisih } \\
\text { s/v (\%) }\end{array}$ & Overheating & $\begin{array}{l}\text { Selisih } \\
\text { Overheating } \\
(\%)\end{array}$ & $\begin{array}{l}\text { Beban } \\
\text { Pendinginan } \\
\text { (kWh/tahun) }\end{array}$ & $\begin{array}{l}\text { Selisih beban } \\
\text { pendinginan } \\
(\%)\end{array}$ \\
\hline $\begin{array}{c}1 \text { (base } \\
\text { case) }\end{array}$ & 0.21 & - & 41.5 & - & $60,713.0$ & - \\
\hline 2 & 0.24 & 12.3 & 42.3 & 1.9 & $69,502.9$ & 14.5 \\
\hline 3 & 0.27 & 30.5 & 55.9 & 34.7 & $76,788.0$ & 26.5 \\
\hline 4 & 0.18 & -13.0 & 40.6 & -2.2 & $59,988.3$ & -1.2 \\
\hline 5 & 0.21 & -0.1 & 43.9 & 5.8 & $63,888.2$ & 5.2 \\
\hline 6 & 0.23 & 11.4 & 49.4 & 19.0 & $73,305.6$ & 20.7 \\
\hline 7 & 0.30 & 41.5 & 46.9 & 13.0 & $73,219.5$ & 20.6 \\
\hline
\end{tabular}

Model 4 sekaligus menjadi model dengan beban pendinginan terendah diantara semua model. Model 3 memiliki beban pendinginan tertinggi diantara semua model. Model 6 dan model 7 memiliki beban pendinginan yang hampir sama. Teori sebelumnya menyatakan bahwa beban pendinginan akan makin besar pada bangunan yang memiliki s/v ratio besar. pada penelitian kali ini, terdapat beberapa kasus yang bertentangan dengan pendapat tersebut [6]. Pertama, model 5 yang memiliki s/v ratio sama dengan model 1 , memiliki beban pendinginan $5 \%$ lebih tinggi. model 7 yang memiliki s/v ratio $41 \%$ lebih besar dari model 1, dan model 6 yang memiliki s/v ratio $11 \%$ lebih tinggi dari model 1 memiliki beban pendinginan yang hampir sama. Beban pendinginan ini bergantung pada aliran panas yang masuk ke dalam bangunan. Aliran panas ini akan mempengaruhi besarnya temperatur ruang dalam bangunan.

Temperatur netral Surabaya adalah $26,5^{\circ} \mathrm{C}$. Semua model mengalami overheating selama jam kerja. Model 3, 6, dan 7 memiliki indoor temperature tertinggi pada pukul 15.00, model 1, 2, 4 dan 5 memiliki indoor temperature tertinggi pada jam 17.00 (gambar 2). Gambar 4.3 menunjukkan profil aliran panas tiap jam pada semua bangunan. jika dibandingkan dengan model dasar, model 2 memiliki jumlah maksimum heat gain pada pukul 17.00 model 2 dan model 1 memiliki rasio luas 
atap dan dinding yang hampir sama sehingga pola rambatan panasnya pun hampir sama dan jumlah heat gain maksimum terletak pada jam yang sama.

Model 4 memiliki selisih luas dinding 28\% lebih kecil dan memiliki luas atap 50\% lebih besar dibandingkan dengan model dasar. Ternyata selisih ini hanya mengakibatkan selisih jumlah beban pendinginan yang cukup sedikit. Pergeseran waktu masuknya panas akibat time lag material tidak terlalu banyak jika dibandingkan model dasar sehingga jumlah heat gain maksimum terletak pada jam yang sama dengan model dasar.

Model 5 memiliki selisih luas dinding dan atap yang cukup kecil. Luas selubung model 5 dan model dasar sama sehingga profil panas model 1 dan 5 hampir sama dan jumlah heat gain maksimum terletak pada jam yang sama dengan model dasar.

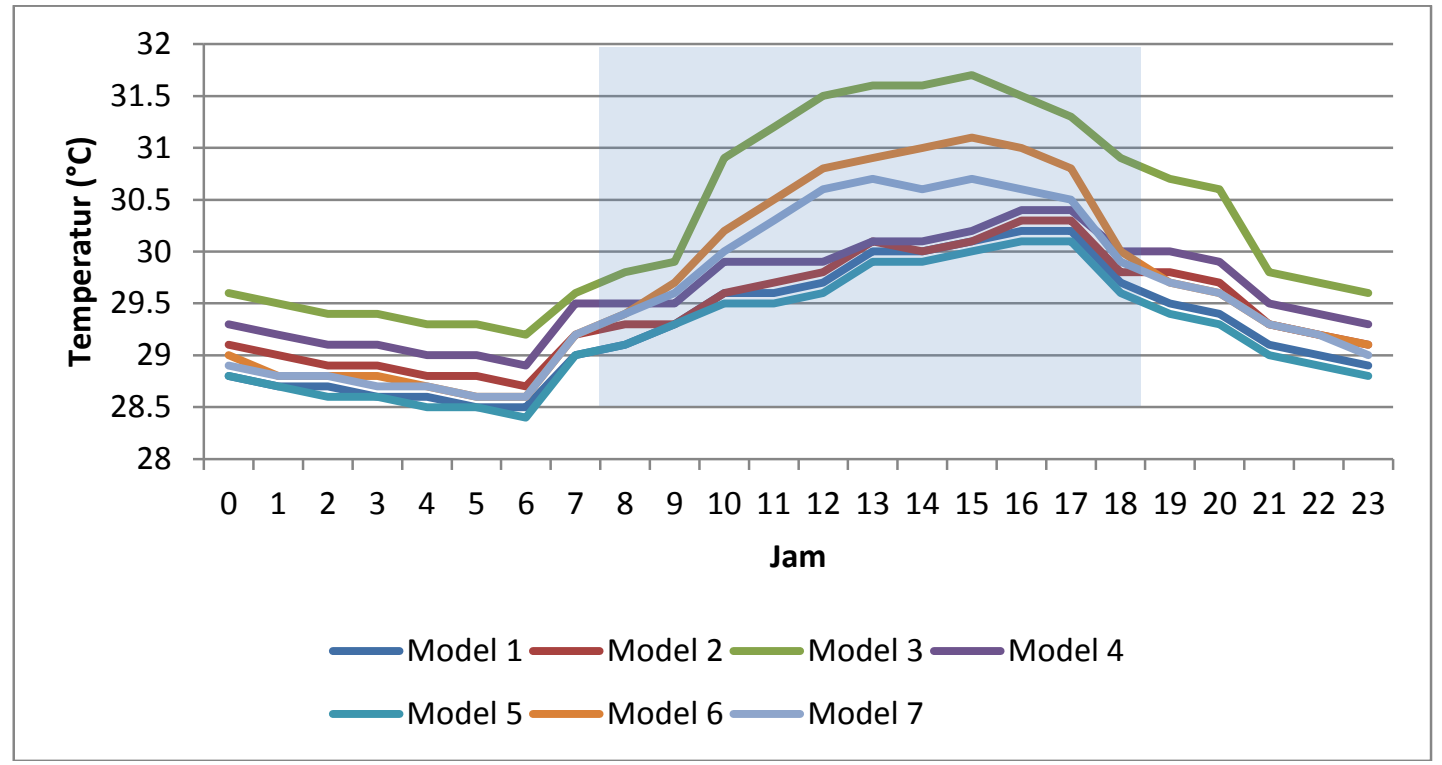

Gambar 2. Indoor temperature pada bulan model 1 s.d. model 7

Tabel 5.Energi pendinginan dan beban pendinginan setiap model

\begin{tabular}{|c|c|c|c|c|c|c|c|}
\hline Model & $\begin{array}{l}\text { Luas } \\
\text { lantai }\end{array}$ & $\begin{array}{l}\text { Selisih } \\
\text { luas lantai } \\
(\%) \\
\end{array}$ & $\begin{array}{l}\text { Beban } \\
\text { Pendinginan } \\
\text { (kWh/tahun) }\end{array}$ & $\begin{array}{l}\text { Selisih } \\
\text { beban } \\
\text { pendinginan } \\
(\%)\end{array}$ & $\begin{array}{l}\text { Energi } \\
\text { pending } \\
\text { inan }\end{array}$ & $\begin{array}{l}\text { Selisih } \\
\text { energi } \\
\text { pendingi } \\
\text { nan }(\%) \\
\end{array}$ & $\begin{array}{l}\text { Selisih } \\
\text { energi } \\
\text { pendinginan } \\
\text { terhadap } \\
\text { standar }(\%) \\
\end{array}$ \\
\hline 1 & 608 & & 60713.00 & - & 141.79 & - & 51 \\
\hline 2 & 730 & 20 & 69502.85 & 14 & 124.95 & -12 & 33 \\
\hline 3 & 606 & 0 & 76788.02 & 26 & 166.26 & 17 & 77 \\
\hline 4 & 914 & 50 & 59988.30 & -1 & 86.15 & -39 & -8 \\
\hline 5 & 529 & -13 & 63888.20 & 5 & 158.50 & 12 & 69 \\
\hline 6 & 696 & 14 & 73305.60 & 21 & 102.78 & -28 & 9 \\
\hline 7 & 527 & -13 & 73219.46 & 21 & 145.65 & 3 & 55 \\
\hline
\end{tabular}

Tabel 5 menunjukkan jumlah energi pendinginan pada setiap model. Model 1 menggunakan energi pendinginan sebesar $141,79 \mathrm{kWh} / \mathrm{m}^{2} /$ Tahun. Bangunan ini tergolong tidak efisien. BPPT [2] menetapkan alokasi energi listrik untuk bangunan perkantoran. Sistem AC menggunakan maksimal 47\% dari seluruh energi listrik yang digunakan pada bangunan. Negara ASEAN menetapkan batas maksimal konsumsi energi listrik untuk bangunan yang efisien sebesar $200 \mathrm{kWh} / \mathrm{m}^{2} / \mathrm{Tahun}$. Jika sistem AC menggunakan $47 \%$ total energi maka bangunan yang efisien dalam penggunaan energi 
pendinginan adalah bangunan yang mengkonsumsi daya listrik untuk AC lebih kecil atau sama dengan $94 \mathrm{kWh} / \mathrm{m}^{2} /$ Tahun. Terdapat tiga model yang lebih efisien dibanding model dasar antara lain model 2, model 4 dan model 6. Diantara ketiga model tersebut yang sudah memenuhi kriteria efisiensi energi hanya model 4. Model 6 menggunakan energi pendinginan sedikit di atas standar.

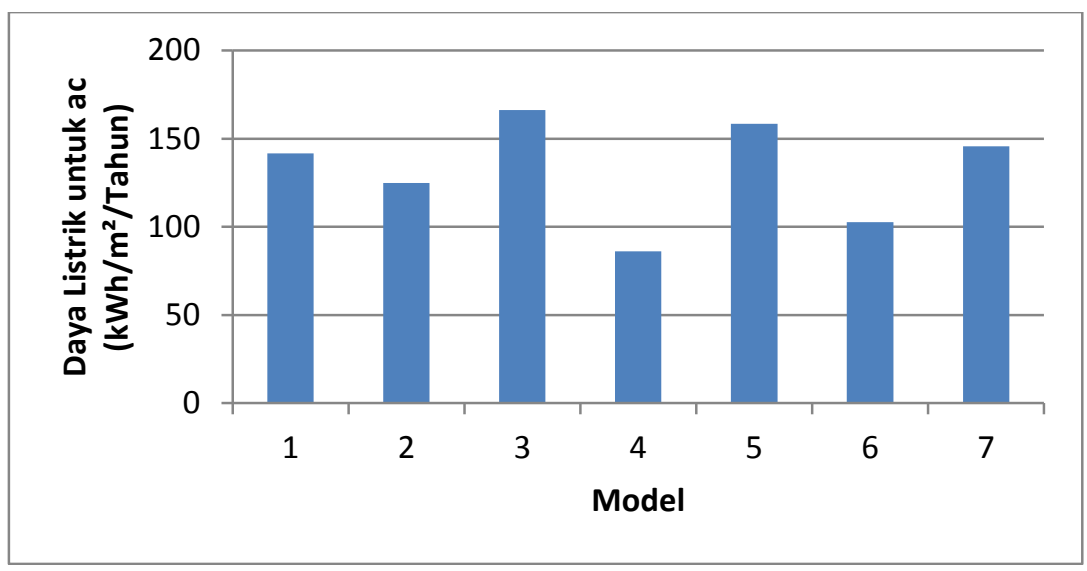

Gambar 3. Energi pendinginan model 1 s.d. model 7

Energi pendinginan dipengaruhi oleh total beban pendinginan dan luas lantai bangunan. Model 2 yang memiliki beban pendinginan 14\% lebih tinggi dari model 1 mengkonsumsi energi $12 \%$ lebih rendah dari model 1 . Hal ini disebabkan oleh luas lantai 2 yang lebih besar $20 \%$ dari model 1 sehingga jika beban pendinginan dibagi dengan luas lantai beban pendinginan per $\mathrm{m}^{2}$ pada model 2 menjadi lebih kecil dari model 1. Model 3 dengan luas lantai yang sama namun beban pendinginan lebih banyak akan mengkonsumsi energi lebih banyak di tiap $\mathrm{m}^{2}$ bangunan. Model 4 merupakan model yang paling efisien. Beban pendinginan pada model 4 juga yang paling kecil (gambar 3) dari semua bangunan. model 5 memiliki beban pendinginan lebih besar dari model 1 dengan luas lantai yang jauh lebih kecil sehingga energi yang dikonsumsi tiap $\mathrm{m}^{2}$ pada model 5 lebih besar dari model 1. Model 6 memiliki beban pendinginan lebih besar dari model dasar namun dengan luas lantai yang lebih besar, model 6 mengkonsumsi energi pendinginan lebih kecil untuk tiap $\mathrm{m}^{2}$. Namun meskipun lebih kecil dari model dasar, model 6 ini belum bisa mencapai standar efisiensi energi. Model 7 dengan luas lantai lebih kecil dari model dasar dan beban pendinginan yang lebih besar mengkonsumsi energi pendiginan lebih besar pada tiap $\mathrm{m}^{2}$.

Jika diurutkan, bangunan dengan kinerja energi terbaik hingga terburuk adalah model 4 , model 6 , model 2 , model 1 , model 7 , model 5 dan model 3 . Hanya model 4 yang mengkonsumsi energi dibawah standar. Dengan luas dinding paling kecil diantara semua model, dan luas dinding barat yang juga terkecil, model 4 memiliki sQc dan sQs terendah. Model 3 memiliki luas dinding yang sangat besar dan dinding timur dan barat model 3 lebih besar dari dinding utara dan selatannya sehingga model 3 memiliki sQc dan sQs paling tinggi.

Dari uraian di atas, disimpulkan bahwa dengan merubah model 1 menjadi model 4, dengan s/v ratio 13\% lebih kecil dan luas lantai 50\% lebih besar akan membuat bangunan menjadi efisien. Model dengan s/v ratio tinggi dan dinding barat dan timur yang lebih besar dari dinding utara dan selatan bangunan merupakan model yang paling tidak efisien karena akan banyak memasukkan panas baik sQc maupun sQs. Hal ini mendukung teori sebelumnya yang menyebutkan bahwa bangunan terbaik adalah bangunan yang memiliki orientasi utara dan selatan [10].

\section{Pengaruh Bentuk Terhadap Energi Pendinginan}

Penelitian terdahulu menyebutkan bahwa beban pendinginan dipengaruhi oleh s/v ratio [6]. Semakin besar s/v ratio maka semakin besar pula beban pendinginan bangunan tersebut. Hasil simulasi pada penelitian kali ini secara umum mendukung teori tersebut. Secara umum, ada keterkaitan antara $\mathrm{s} / \mathrm{v}$ ratio dan total beban pendinginan namun pada penelitian ini terdapat beberapa kasus yang tidak sesuai dengan teori tersebut (gambar 4). Model 5 dengan s/v ratio sama 
memiliki beban pendinginan 5\% lebih besar dari model 1, hal ini disebabkan oleh alian panas secara konduksi konduksi model 5 14\% lebih besar dari model 1 dan alan panas dari radiasi pada model $523 \%$ lebih besar dari model 1 (Tabel 6).

Pada bangunan bertingkat yang paling banyak mempengaruhi beban pendinginan adalah dinding, karena bangunan bertingkat rata-rata memiliki luas dinding yang lebih besar dibanding atap [2]. Tabel 3 menunjukkan perbandingan luas dinding total pada setiap model terhadap model dasar. Pada model 2 s.d. model 6, sQc akan bertambah seiring dengan bertambahnya luas dinding. Merubah model 1 menjadi model 4 yang memiliki luas dinding lebih kecil akan menyebabkan aliran panas secara konduksi pada bangunan lebih rendah (tabel 6).

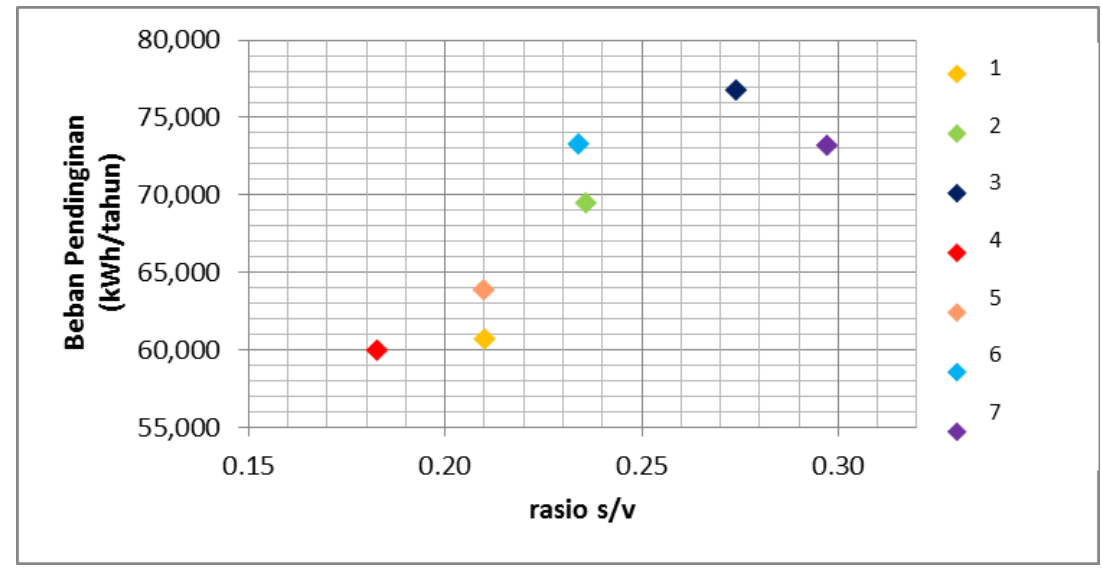

Gambar 4. Hubungan antara beban pendinginan dan s/v ratio

Tabel 6. Perbandingan Aliran Panas secara konduksi pada selubung bangunan (sQc), luas dinding, dan beban pendinginan terhadap model dasar

\begin{tabular}{|c|c|c|c|c|}
\hline Model & $\begin{array}{l}\text { Selisih luas } \\
\text { dinding } \\
\text { dengan Base } \\
\text { Case }(\%)\end{array}$ & $\begin{array}{l}\text { Selisih sQc } \\
\text { dengan Base } \\
\text { Case }(\%)\end{array}$ & $\begin{array}{l}\text { Beban } \\
\text { Pendinginan } \\
\text { (kWh/Tahun) }\end{array}$ & $\begin{array}{l}\text { Selisih beban } \\
\text { pendinginan } \\
\text { dengan Base Case } \\
(\%)\end{array}$ \\
\hline 1 (BC) & & - & 60713.00 & - \\
\hline 2 & 11 & 28 & 69502.85 & 14 \\
\hline 3 & 39 & 70 & 76788.02 & 26 \\
\hline 4 & -28 & -58 & 59988.30 & -1 \\
\hline 5 & 4 & 26 & 63888.20 & 5 \\
\hline 6 & 9 & 33 & 73305.60 & 21 \\
\hline 7 & 13 & -9 & 73219.46 & 21 \\
\hline
\end{tabular}

\section{SIMPULAN}

Hasil evaluasi secara umum menunjukkan bahwa kinerja energi pada bangunan bertingkat menengah di Surabaya buruk. Dari tujuh model hanya satu model yang memenuhi kriteria efisiensi energi yaitu model dengan bentuk oktagon (model 4). Jika dibandingkan dengan model dasar, bentuk oktagon memiliki prosentase dinding lebih $28 \%$ lebih rendah sehinggga jumlah panas baik secara konduksi lebih kecil. Model oktagon memiliki prosentase dinding barat paling kecil sehinggga panas yang masuk karena radiasi juga kecil. Dengan volume yang sama, bentuk oktagon memiliki luas lantai 50\% lebih besar dari model dasar, sehingga jumlah energi pendinginan di tiap $\mathrm{m} 2$ menjadi $39 \%$ lebih rendah.

Dengan volume bangunan yang sama, model yang paling efisien adalah bentuk oktagon dengan material dinding bata konvensional dan clear glass. Bangunan dengan bentuk lain dapat 
menjadi bangunan yang efisien dengan menggunakan kombinasi material berbeda pada dinding dan kaca.

Teori sebelumnya menyatakan meningkatnya $\mathrm{s} / \mathrm{v}$ ratio mengakibatkan naiknya beban pendinginan [6]. Dalam penelitian kali ini terdapat satu kasus dimana model 7 memiliki s/v ratio paling besar namun beban pendinginan model 7 bukan yang terbesar diantara semuanya. Satu kasus lainnya, dimana s/v ratio model 1 sama degan s/v ratio model 5 namun beban pendinginan model 5 lebih tinggi dari model 1 . Perbedaan ini terjadi karena pada penelitian sebelumnya radiasi yang menimpa seluruh selubung bangunan di tiap orientasi dianggap sama. Hasil dari penelitian ini menunjukkan bahwa dengan s/v ratio sama, luas dinding timur dan barat model 5 lebih besar maka radiasi matahari yang diterima juga makin besar sehinggga menyebabkan beban pendinginan model 5 lebih tinggi dari model 1 . Hal ini mendukung hasil penelitian terdahulu[14], walaupun memiliki s/v ratio sama, bentuk yang berbeda akan memiliki beban pendinginan yang berbeda pula karena perbedaan bentuk akan mempengaruhi jumlah radiasi yang menerpa bangunan.

Beban pendinginan akan lebih tinggi pada bangunan dengan luas dinding besar. Hasil penelitian kali ini menunjukkan bahwa prosentase luas dinding lebih banyak berpengaruh pada besarnya beban pendinginan dibandingkan prosentase luas atap. makin besar luas dinding maka makin besar pula sQc pada bangunan. Bangunan yang memiliki dinding barat dan timur sama atau lebih besar dari dinding utara dan selatannya akan menerima lebih banyak radiasi. Semakin besar rasio dinding barat dan timur tehhadap selubung, makin besar pula sQs pada bangunan. Hal ini sama dengan hasil penelitian sebelumnya [4], bangunan bertingkat paling banyak memasukkan panas dari dinding dibanding elemen lainnya.

Teori sebelumnya menyatakan bahwa merubah bentuk bangunan tidak terlalu banyak pengaruhnya terhadap energi operasional dibandingkan merubah material dinding [15]. Pada penelitian kali ini didapat perbedaan bentuk akan sangat mempengaruhi beban pendinginan dan energi operasional bangunan. Perbedaan hasil penelitian ini dengan penelitian tersebut [15] terletak pada parameter bentuk yang digunakan. Pada penelitian sebelumnya menguji pengaruh s/v ratio dengan surface yang sama dan volume yang berbeda sedangkan pada penelitian kali ini menguji pengaruh bentuk degan surface yang berbeda dengan volume sama.

Merubah kombinasi material dinding memiliki pengaruh lebih besar dibanding merubah bentuk bangunan. Dengan kombinasi material tertentu, bangunan yang memiliki kinerja energi buruk akan dapat menjadi bangunan yang efisien. Penelitian sebelumnya menghasilkan pernyataan bahwa merubah bentuk akan memiliki pengaruh yang lebih besar terhadap beban pendinginan dari pada meningkatkan kualitas material dinding [16]. Pada penelitian sebelumnya, perbedaan kualitas material dinding disebabkan oleh penebalan insulasi pada dinding, sedangkan pada penelitian kali ini, peningkatan kualitas dinding disebabkan oleh perubahan jenis material dan thermal properties material serta kombinasi material dinding dan kaca.

\section{DAFTAR PUSTAKA}

[1] Priatman Jimmy (2002), "Energy-Efficient Architecture" Paradigma Dan Manifestasi Arsitektur Hijau. FT UK Petra: Dimensi Teknik Arsitektur vol 31 no 1

[2] Hilmawan Edi dan Said Mustafa (2009), "Energy Efficiency Standart and Labeling Policy in Indonesia", International cooperation for Energy Efficiency Standart and Labelinmg Policy, Tokyo

[3] Knowles, R.L. (2003), “The Solar Envelope: Its Meaning for Energy and Buildings”, Journal of Energy and Buildings

[4] Yeang Ken (1996), The Green Skyscraper. London: Prestel

[5] Baker Nick dan Koen Steemers, (2005), Energy and Environmental in Architecture, Taylor \& Francis Group, New York

[6] Markus T.A, Morris E.N (1980), Buildings, Climate and Energy, Pitman Publishing Limited, London

[7] Juniwati Anik dan Asri Dinapradipta (2008), "Optimum Façade Design For Energy Efficient High-Rise Office Building In Hot Humid Tropics", Proceidings 9th SENVAR + 2nd ISESEE 2008, Malaysia 
[8] Depecker P, C. Menezo, J. Virgone, S. Lepers (2001), "Design of buildings shape and energetic consumption", Science Direct, Building and Environment 36 (2001) 627-635

[9] Ling C.S (2007), Minimising Solar Insolation In High Rise Buildings Trough Self Shaded Form, Universiti Teknologi, Malaysia

[10] Olgyay, V (1963). Design with Climate- Bioclimatic approach to architectural regionalism, Princeton University Press, New Jersey

[11] Heerwagen Dean, 2004, Passive and Active Environmental Controls Informing The Schematic Design of Building, Mc Graw Hill, New York

[12] Gonzalo Roberto dan Karl J Hbermann (2006), Energy Efficient Architecture, Birkhauser, Berlin

[13] Chirarattananon Surapong \& Juntakan Taveekun, "An OTTV-based energy estimation model for commercial buildings in Thailand", Science Direct, Energy and Buildings 36 (2004) 680 689

[14] Zerefos Stelios C, Christos A. Tessas, Anastasios M. Kotsiopoulos, Dimitra Founda, Angeliki Kokkini (2012), The role of building form in energy consumption: The case of a prismatic building in Athens. Science Direct: Energy and Buildings 48 (2012) 97-102

[15] Crawford Robert H, Czerniakowski Isabella, Fuller Robert J (2010), "A comprehensive framework for assessing the life cycle energy of building construction assemblies", Science Direct, Architectural Science Review 53 (2010) 288-296

[16] Gratia Elisabeth dan Herde Andre De (2003), "Design of low energy office building", Science Direct, Energy and Buildings 35 (2003) 473-491 